\title{
The macrophage at the intersection of immunity and metabolism in obesity
}

\author{
M Constantine Samaan
}

\begin{abstract}
Obesity is a worldwide pandemic representing one of the major challenges that societies face around the globe. Identifying the mechanisms involved in its development and propagation will help the development of preventative and therapeutic strategies that may help control its rising rates.

Obesity is associated with chronic low-grade inflammation, and this is believed to be one of the major contributors to the development of insulin resistance, which is an early event in obesity and leads to type 2 diabetes when the pancreas fails to keep up with increased demand for insulin. In this review, we discuss the role of macrophages in mediation of inflammation in obesity in metabolic organs including adipose tissue, skeletal muscle and liver. The presence of immune cells at the interface with metabolic organs modulates both metabolic function and inflammatory responses in these organs, and may provide a potential therapeutic target to modulate metabolic function in obesity.
\end{abstract}

Keywords: Obesity, type 2 diabetes, inflammation, macrophage, cytokines, chemokines, muscle, adipose tissue, liver

\section{Introduction}

More than one billion people around the world are overweight or obese, and one in eight of those is a child [1]. Another worldwide pandemic is type 2 diabetes, with around 350 million people affected[2] and this is mostly related to obesity. The burdens of obesity and diabetes with their co-morbidities on the individual, family, community, health care systems, and society at large is one of the biggest challenges that societies face around the globe[3]. Understanding the mechanisms involved in the development of the two conditions paves the way for design of preventative and therapeutic strategies that may stem their progress.

In this review, we highlight the role of the macrophage, an immune cell, in the development of obesitymediated inflammation. We review the evidence for the intersection of nutrient and cytokine sensing in immune and metabolic organs, and assess the evidence for presence and actions of macrophages in metabolic organs.

\footnotetext{
Correspondence: samaanc@mcmaster.ca Division of Pediatric Endocrinology, Department of Pediatrics, McMaster Children's Hospital, McMaster University, 1200 Main Street West, Hamilton, Ontario, Canada
}

(c) 2011 Samaan; licensee BioMed Central Ltd. This is an Open Access article distributed under the terms of the Creative Commons Attribution License (http://creativecommons.org/licenses/by/2.0), which permits unrestricted use, distribution, and reproduction in any medium, provided the original work is properly cited.

\section{Nutrient sensing, cytokine signaling and inflammation in obesity}

It is well established that obesity is associated with inflammation[4-15], but this inflammation is different from that seen in infection or autoimmunity. First, obesity-associated inflammation does not fulfill the usual description of acute inflammation with redness, heat, swelling, and pain but follows a more chronic and lowgrade course[16-19]. Second, inflammation in obesity is a systemic process that affects many organs, but may begin in one or more organs. Inflammation starts in adipose tissue as it expands with excess fat and caloric intake, and involves activation of inflammatory pathways in cells by nutrient-sensing and cytokine signaling. Nutrient sensing occur via pattern recognition receptors including membrane-based innate immune receptors known as toll-like receptors 2 and 4 (TLR2 \& TLR4), and intracellular pathogen sensing NOD-like receptors [20-24]. These receptors were originally thought to be involved only in pathogen sensing, but recently were found to sense fatty acids.

In addition, cytokines are produced in response to inflammatory stimuli from different organs, and can act in an autocrine, paracrine or endocrine fashion [25-30]. Fatty acids and cytokines converge to activate 
the same downstream inflammatory pathways. The activation of these pathways leads to production of transcription factors that enter the nucleus and activate inflammatory cytokine gene expression and cytokine production, leading to propagation of inflammation[31-34](Figure 1).

Recently, an intriguing mechanism was proposed as an explanation for obesity. CNS deletion of Toll-like receptor 4(TLR4) adaptor MyD88 protected mice from high fat diet-mediated obesity. Intracerebroventricular administration of saturated fatty acid palmitate did not elicit leptin or insulin resistance and did not increase hypothalamic inflammatory cytokines. This indicates that high fat diet in part acts centrally even before meaningful weight gain to trigger leptin and insulin resistance. This leads to dysregulation of anorexigenic effects of leptin and insulin, and initiation and progression of obesity[35]. Hypothalamic inflammation as a starting point for obesity is an interesting mechanism that requires further study $[36,37]$.

Immune cells in metabolic organs drive inflammation in obesity

While many mechanisms leading to inflammation in obesity are not completely understood, it is clear that the interaction between immune and metabolic cells initiates and propagates the inflammatory response.

Adipose tissue expansion in obesity outpaces its blood supply, resulting in adipose tissue hypoxia and activation of inflammatory responses, with production of factors including Hypoxia Inducible Factor-1 $\alpha$ [HIF-1 $\alpha$ ][38]. It

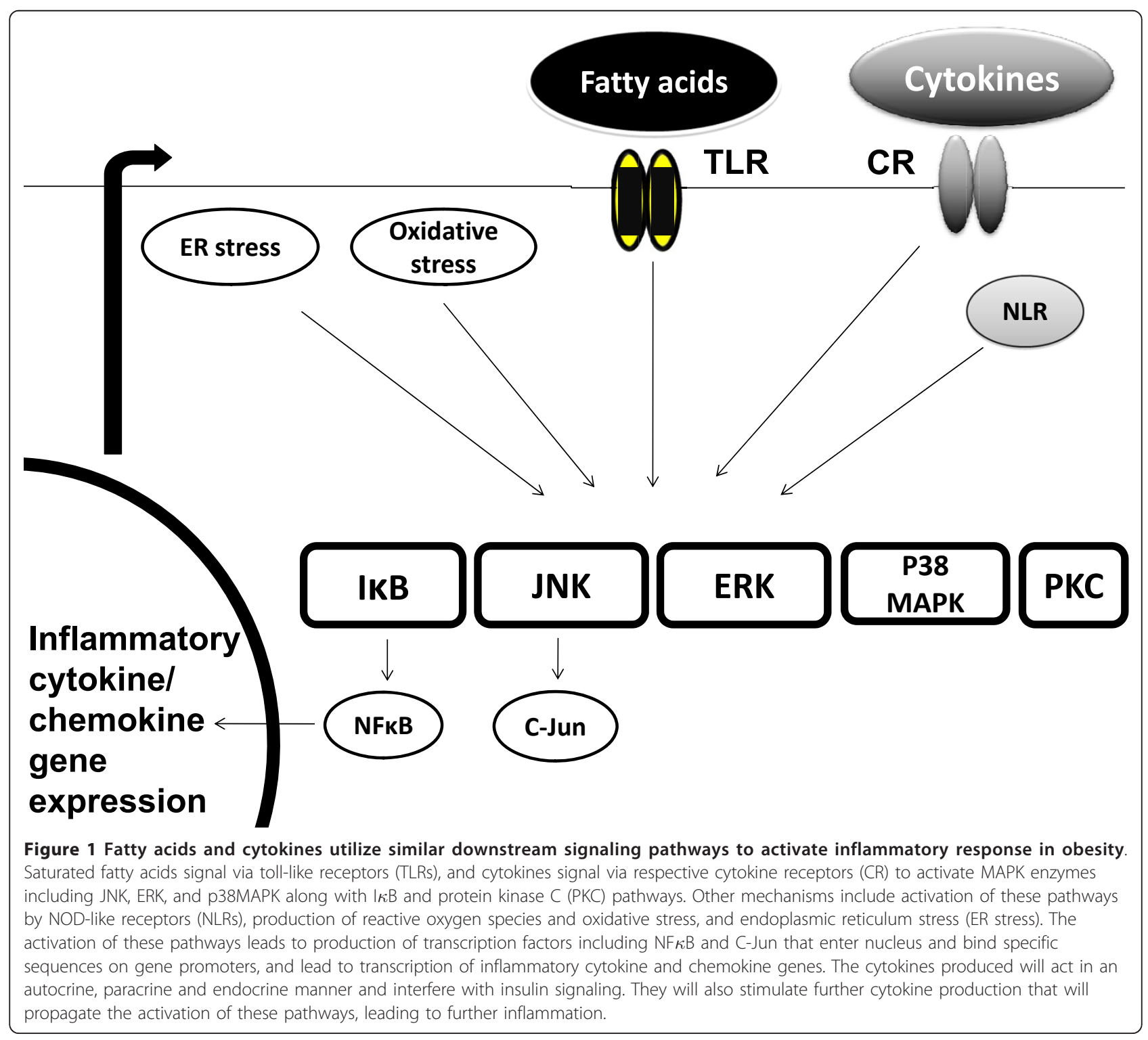


is also associated with altered adipokine production with enhanced production of leptin and resistin, and reduced production of adiponectin [39-50].

In addition, inflammation results in secretion of cytokines and chemokines. This will activate adipose tissue $\mathrm{T}$ - lymphocytes and resident macrophages, which are present in adipose tissue under physiological conditions. This then leads to secretion of pro-inflammatory cytokines and chemokines from these cells that attract immune cells including other T-lymphocytes, neutrophils, and monocytes[16,18,51-60]. Once in adipose tissue, monocytes differentiate to macrophages, and start secreting cytokines that propagate local inflammation in adipose tissue.

\section{Inflammatory pathway activation drives inflammation and insulin resistance in obesity}

Inflammation mediated by increased cytokine production and excess fatty acids or 'lipotoxicity' activate inflammatory pathways in immune and metabolic cells. These pathways include Mitogen Activated Protein Kinase (MAPK) pathway members including c-jun amino terminal kinase (JNK), Extracellular Regulated Kinase (ERK), and p38MAPK. In addition $\mathrm{I} \kappa \mathrm{B}$ kinase [61-69] and protein kinase $C$ (PKC)[70-73] pathways are also activated. The activation of these pathways leads to interference with insulin signaling leading to insulin resistance, an early event in obesity[16,53-57]. Insulin resistance leads to mitigation of anti-lipolytic effect of insulin on adipose tissue, and lipolysis ensues with local fatty acid release triggering further local inflammation. What begins as a local process eventually exceed the capacity of adipose tissue to contain it, and cytokines and free fatty acids are released into the circulation and reach metabolic organs including skeletal muscle and liver[74,75].

In skeletal muscle, this is compounded by the presence of Intermyocellular Fat Depot [IMFD] that expands with obesity and harbors immune cells including macrophages[76](Figure 2).

In addition, fatty acid uptake into muscle cells leads to accumulation of intracellular triglycerides, which act as a sink to protect muscle from lipotoxicity. Interestingly, athletes have excess triglyceride stores in skeletal muscle, but demonstrate enhanced insulin sensitivity. This 'athlete's paradox' hints to the fact that triglycerides are not the culprits in mediating inflammation and insulin resistance, but it is metabolic intermediates like ceramide and diacylglycerol generated intracellularly that interfere with insulin signaling and trigger inflammation[77-79].

The deposition of fat into the liver leads to fatty liver with activation of inflammatory pathways, secretion of inflammatory cytokines, monocyte attraction and macrophage generation, which in turn leads to hepatic inflammation and insulin resistance $[32,80]$.

The initial response to compensate for insulin resistance is via increased insulin production by pancreatic $\beta$-islet cells, leading to hyperinsulinemia. Eventually, the pancreas fails to maintain insulin production in the face of steadily increasing insulin demand, leading to the development of type 2 diabetes.

\section{Inflammation is associated with macrophage infiltration of metabolic organs}

The detection of enhanced expression of Tumor Necrosis Factor- $\alpha$ [TNF- $\alpha$ ], a prototypical inflammatory cytokine, in adipose tissue in obese mice provided first clues to presence of inflammation in obesity[81]. This was then confirmed in obese and diabetic humans[4]. The source of TNF- $\alpha$ was initially presumed to be the adipocyte, but it was eventually found to be from an immune cell, the macrophage[16,18,82-85]. These cells produce multiple cytokines and chemokines in obesity that modulate function of metabolic organs leading to inflammation and insulin resistance[83-85].

Macrophages are mononuclear phagocytic cells that are part of the innate immune system, an evolutionarily conserved defense system with cells placed at ports of entry of pathogens and other environmental threats to the body[86-88]. One function for these cells is sampling antigens as they enter the body and then either destroy them by an 'innate response' with no memory kept of the encounter, or present the antigen to the T-lymphocytes to mount an adaptive immune response[27,86]. The precursors of macrophages, the monocytes, are generated in the bone marrow. These cells are recruited to adipose tissue by signals from adipocytes and adipose tissue macrophages[89,90]. Once in the adipose tissue, the monocytes differentiate to macrophages[91].

\section{Phenotypic characterization of macrophages in metabolic organs}

Adipose tissue

Early in obesity, adipocytes are predominantly responsible for producing chemokines and macrophages are involved in producing cytokines, but both cells are capable of producing these molecules, and can modulate function of metabolic organs leading to inflammation and insulin resistance[83-85]. Adipose tissue macrophages are present in two main subtypes. The resident or 'M2' macrophages are present in almost all organs in the body as resident cells under physiological conditions, where they serve to maintain tissue homeostasis[92-95]. Under normal physiological states, 5-10\% of adipose tissue cells are resident M2 macrophages. These cells are distinguished by being responsive to IL- 4 and IL-13 and 


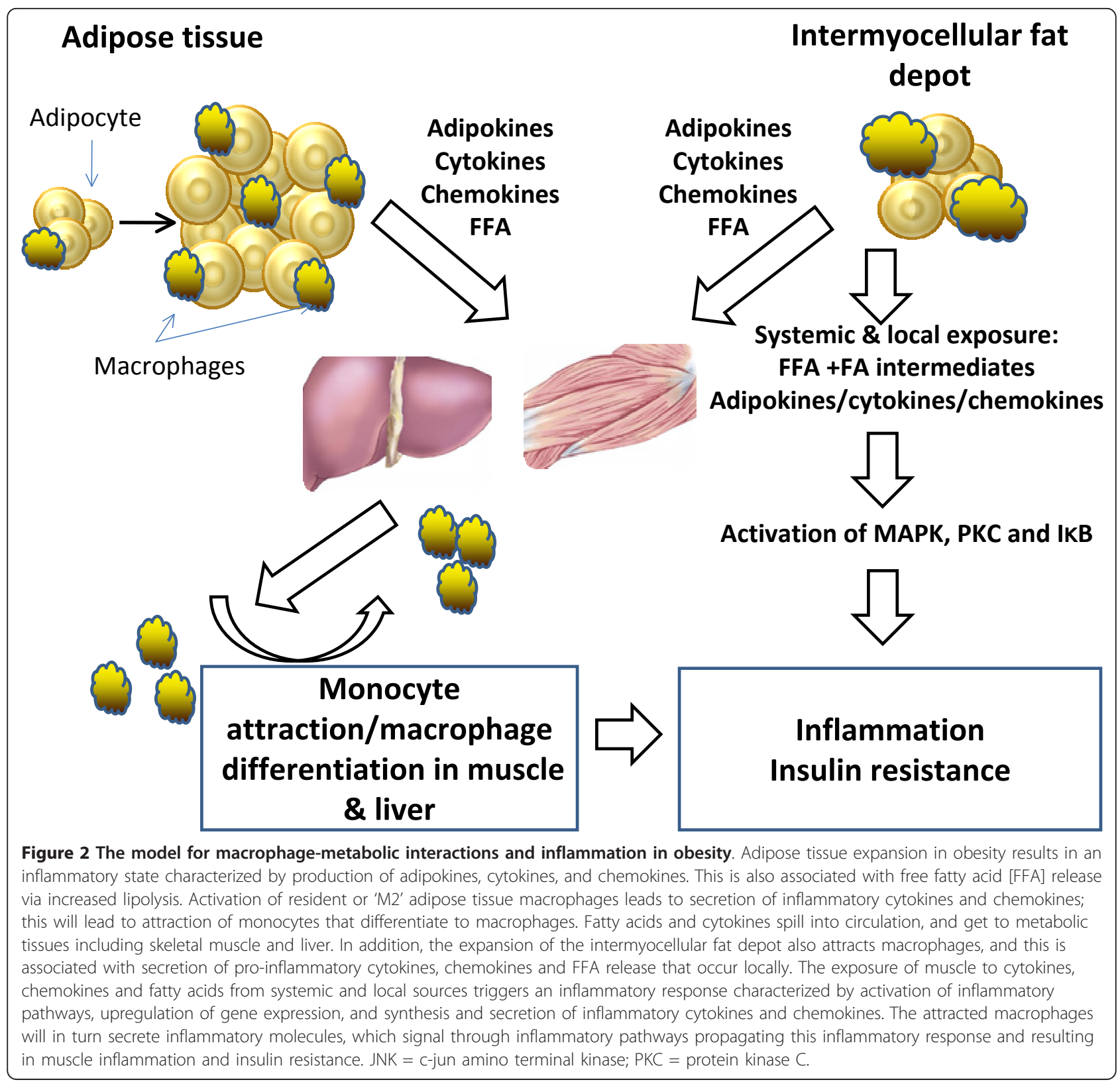

their ability to secrete anti-inflammatory cytokines like IL-10.

In addition, M2 macrophages upregulate production of Arginase I enzyme, reducing nitric oxide synthesis and inflammation via metabolizing arginine to ornithine [92,93,96-100]. Arginase I gene expression is stimulated by IL- 4 and Signal Transducer and Activator of Transcription-6 (STAT-6) axis[101]. This in turn signals via the master regulator of adipogenesis and fatty acid sensor Peroxisome Proliferator-Activated Receptor gamma (PPAR $\gamma$ ).

PPAR/RXR heterodimers bind to specific sequences at the Arginase I gene enhancer region activating its expression[102]. PPAR $\gamma$ is essential for attainment and preservation of M2 macrophage phenotype, as its deletion in macrophages leads to excess adiposity in mice on high fat diet. It also results in insulin resistance in skeletal muscle and liver in these mice. When adipocytes are co-incubated with PPAR $\gamma$ knockout macrophages, they become insulin resistant, which argues for factors produced by these macrophages, including IL-4 among others, that modulate metabolic function in adipose tissue, liver and skeletal muscle[102,103].

On the other hand, bone marrow-derived monocytes migrating into obese adipose tissue and exposed to fatty acids and cytokines differentiate to an inflammatory or 
'M1' macrophages [89,91,104,105]. M1 macrophages are responsive to interferon gamma and lipopolysaccharide, and are capable of producing pro-inflammatory cytokines and nitric oxide. Their numbers increase several folds with obesity and high fat feeding[18].

The M1/M2 divide is a simplistic view of the reality of macrophage existence in different organs[106,107]. Macrophages very likely exist in multiple intermediate phenotypes depending on local tissue microenvironment $[98,99]$, and are able to respond to local cues and shift their phenotype to maintain local tissue homeostasis.

Another consideration is that while M1 macrophages in obese adipose tissue originate mainly from bone marrow [90], it is possible that other cells may contribute to this pool. The pre-adipocyte may be a potential source of macrophages in obese adipose tissue, as these cells share common capabilities with macrophages in response to obesogenic environments.

Pre-adipocytes reside in stromal vascular fraction within adipose tissue, and are bathed in the same cocktail of nutrients and cytokines that influence their interactions with other cells in that environment[108-110]. Macrophages are capable of storing lipids as seen in foam cells present in atherosclerotic plaques, and foamlike cells are also seen in obese adipose tissue[111-113]. Pre-adipocytes injected into peritoneal cavity of mice can act like macrophages, with phagocytosis of microorganisms and posses antimicrobial actions via generation of reactive oxygen species $[108,110]$. These abilities disappear when cells differentiate to mature adipocytes.

Pre-adipocytes can also differentiate to macrophages with expression of many macrophage markers[108], and this is probably due to direct physical contact between pre-adipocyte and macrophage. In addition, the transcriptional profile of pre-adipocyte is in fact closer to the macrophage than to the adipocyte, and these cells produce many common products to both including cytokines, chemokines, and adhesion molecules $[108,110,114,115]$.

More recently, weight loss in mice previously fed high fat diet lead to infiltration of adipose tissue with M2 macrophages. This was mediated by lipolysis, and macrophages were acting as neutralizers of effects of excess fat in obese adipose tissue [74]. This is in contrast to when weight gain leads to the infiltration of M1 macrophages, and argues for a robust immune response to local adipose tissue microenvironment, and this M2 infiltration may be an attempt to protect adipose tissue from mounting an inflammatory response with excess local fatty acid concentrations. The ultimate aim of inflammation is the induction of tissue remodeling and to restore homeostasis, and M2 macrophages act to initiate and propagate this process with weight loss[116,117], and depending on local tissue microenvironment, there is potential plasticity in cell phenotype.

\section{Skeletal muscle}

In skeletal muscle, circulating cytokines and fatty acids and those produced locally from IMFD [e.g. TNF $\alpha$, IL6] jointly affect muscle. Macrophages infiltrate IMFD when it expands in obesity [18], and as the IMFD depot is in immediate vicinity of skeletal muscle, it is likely that muscle-macrophage crosstalk will impact both cells. Insulin resistance in muscle is caused by several mechanisms including fatty acid oxidation defects due to effects on mitochondrial biogenesis, oxidative stress, accumulation of lipid intermediates in muscle, and effects of pro-inflammatory cytokine on insulin signaling [57,61,118-122].

Macrophage products from saturated fatty acid treatment in-vitro causes skeletal muscle insulin resistance [123]. The question whether macrophages infiltrate skeletal muscle in obesity is important, as muscle takes up to $75 \%$ of carbohydrate intake after a meal, making it a major determinant of postprandial glycemic status.

There is increasing evidence that macrophages may infiltrate skeletal muscle in obesity. In rodents, high fat feeding increases macrophage infiltration in muscle compared to normal chow fed animals [124]. In addition, deletion of PPAR $\gamma$ in myeloid cells, a master regulator of adipogenesis and inflammation, also resulted in increased macrophage and dendritic cell markers in muscle [125]. Macrophage markers have been documented mainly in IMFD, and rarely between myofibrils with high fat feeding using immunohistochemistry $[18,124]$ and bone marrow transplant experiments [126]. In the latter case, macrophages were detected at the muscle-fat junction, raising the question of whether their location denotes a non-directional chemokinetic response, or a true directional, chemotactic response to factors produced by muscle.

Furthermore, dendritic cell were detected in muscle from high fat fed mice, and fatty acid treatment of bone marrow derived macrophages [BMDM] and dendritic cells $[\mathrm{BMDC}]$ induced inflammation in the BMDC and not BMDM [126].

In human studies, macrophages were detected in skeletal muscle from obese non-diabetic subjects and this was positively associated with body mass index and negatively associated with insulin sensitivity [127]. Macrophages were also detected in human muscle from subjects with normal glucose tolerance but at much lower levels than in adipose tissue [128].

However, other studies failed to demonstrate the presence of macrophage markers using microarrays of muscle from high fat fed mice [16] and no increase of macrophage markers in muscle was noted in severely 
obese humans undergoing lifestyle intervention program [129].

While the above studies provide evidence for and against the infiltration of skeletal muscle by macrophages, there are also challenges to pinpoint the mechanisms of muscle-macrophage interaction in obesity. First, whole tissue analysis for presence of macrophage markers does not necessarily clarify the location of these macrophages, as they could be adherent to the endothelium within blood vessel lumen rather than infiltrating into muscle tissue when tissues are prepared for analysis. Second, a significant challenge is to clarify if these macrophages are in fact infiltrating within muscle fibers or are they mainly in the IMFD that expands in obesity and attracts macrophages. The potential mechanisms and pathways involved in macrophage recruitment to muscle remain incompletely understood.

\section{Liver}

The accumulation of fat in the liver causes Non-alcoholic fatty liver disease (NAFLD) which is an important complication of obesity[130]. Resident liver macrophages [Kupffer cells] play a significant protective role in obesity by producing anti-inflammatory cytokines e.g. IL-10, and their depletion results in hepatic inflammation and insulin resistance[131]. In addition, obesity leads to macrophage recruitment to the liver via their Chemokine $\mathrm{C}-\mathrm{C}$ receptor-2 (CCR2) in response to Chemokine C-C ligand-2 (CCL2) produced by hepatocytes, and these cells regulate hepatic lipid accumulation in the liver[132,133].

In addition, the depletion of resident liver macrophages [Kupffer cells] leads to protection from effects of high fat feeding-induced inflammation.

The association of liver inflammation via the production of inflammatory cytokines including TNF $\alpha$ and IL6 has recently been also linked to the development of hepatocellular carcinoma via stimulation of STAT-3 [134]. As obesity is associated with risk of several cancers, this is a novel area of research that requires further investigation to clarify the link between obesity, inflammation and cancer.

\section{Conclusions}

In summary, obesity is associated with chronic lowgrade inflammation, and macrophage crosstalk with metabolic organs mediates this inflammatory response. Macrophage precursors are recruited to metabolic organs in obesity, and produce several factors that lead to inflammation and insulin resistance in these organs.

The Inflammatory process seen in obesity is caused by the activation of several pathways activated by nutrients including fatty acids and cytokines. The collusion of these stimuli leads to interference with insulin signaling and insulin resistance (Figure 2), which is an early step on the path to type 2 diabetes.

Defining the mechanisms by which different pathways and molecules modulate progression of inflammation in obesity holds the promise of developing interventions that may help hundreds of millions of people around the world struggling with obesity and type 2 diabetes.

\section{Acknowledgements}

The author wishes to acknowledge research support from new investigator fund grant from Hamilton Health Sciences, Hamilton, Ontario, Canada. The author also acknowledges funding support from the Canadian Pediatric Endocrine Group (CPEG).

\section{Competing interests}

The author declares that they have no competing interests.

Received: 23 July 2011 Accepted: 28 October 2011

Published: 28 October 2011

\section{References}

1. WHO Fact sheet: Obesity and overweight. [http://www.who.int/ dietphysicalactivity/publications/facts/obesity/en/], (Accessed July-12th2011).

2. Danaei G, Finucane MM, Lu Y, Singh GM, Cowan MJ, Paciorek CJ, Lin JK, Farzadfar F, Khang Y-H, Stevens GA, et al: National, regional, and global trends in fasting plasma glucose and diabetes prevalence since 1980: systematic analysis of health examination surveys and epidemiological studies with 370 country-years and 2.7 million participants. The Lancet 2011, 378(9785):31-40

3. Kelly T, Yang W, Chen CS, Reynolds K, He J: Global burden of obesity in 2005 and projections to 2030. Int J Obes 2008, 32(9):1431-1437.

4. Hotamisligil GS, Arner P, Caro JF, Atkinson RL, Spiegelman BM: Increased adipose tissue expression of tumor necrosis factor-alpha in human obesity and insulin resistance. J Clin Invest 1995, 95(5):2409-2415.

5. Hotamisligil GS, Shargill NS, Spiegelman BM: Adipose expression of tumor necrosis factor-alpha: direct role in obesity-linked insulin resistance. Science 1993, 259(5091):87-91.

6. Schenk S, Saberi M, Olefsky JM: Insulin sensitivity: modulation by nutrients and inflammation. J Clin Invest 2008, 118(9):2992-3002.

7. Asferg C, Jensen JS, Marott JL, Appleyard M, Mogelvang R, Jensen GB, Jeppesen J: Markers of inflammation and hemodynamic measurements in obesity: Copenhagen City Heart Study. Am J Hypertens 2009, 22(4):451-456.

8. Bullo M, Casas-Agustench P, Amigo-Correig P, Aranceta J, Salas-Salvado J: Inflammation, obesity and comorbidities: the role of diet. Public Health Nutr 2007, 10(10A):1164-1172.

9. Clement K, Vignes S: [Inflammation, adipokines and obesity]. Rev Med Interne 2009, 30(9):824-832.

10. Ferrante AW Jr: Obesity-induced inflammation: a metabolic dialogue in the language of inflammation. J Intern Med 2007, 262(4):408-414.

11. Greenberg AS, Obin MS: Obesity and the role of adipose tissue in inflammation and metabolism. Am J Clin Nutr 2006, 83(2):461S-465S.

12. Hotamisligil GS: Inflammation and endoplasmic reticulum stress in obesity and diabetes. Int J Obes (Lond) 2008, 32 Suppl 7: S52-54.

13. Hurt RT, Frazier TH, Matheson PJ, Cave MC, Garrison RN, McClain CJ, McClave SA: Obesity and inflammation: III. Curr Gastroenterol Rep 2007, 9(4):307-308

14. Hurt RT, Frazier TH, Matheson PJ, Cave MC, Garrison RN, McClain CJ, McClave SA: Obesity and inflammation: II. Curr Gastroenterol Rep 2007, 9(4):306-307.

15. Hardy OT, Perugini RA, Nicoloro SM, Gallagher-Dorval K, Puri V, Straubhaar J, Czech MP: Body mass index-independent inflammation in omental adipose tissue associated with insulin resistance in morbid obesity. Surgery for Obesity and Related Diseases 2011, 7(1):60-67.

16. Xu H, Barnes GT, Yang Q, Tan G, Yang D, Chou CJ, Sole J, Nichols A Ross JS, Tartaglia LA, et al: Chronic inflammation in fat plays a crucial role 
in the development of obesity-related insulin resistance. J Clin Invest 2003, 112(12):1821-1830.

17. Neels JG, Olefsky JM: Inflamed fat: what starts the fire? J Clin Invest 2006, 116(1):33-35.

18. Weisberg SP, McCann D, Desai M, Rosenbaum M, Leibel RL, Ferrante AW Jr: Obesity is associated with macrophage accumulation in adipose tissue. $J$ Clin Invest 2003, 112(12):1796-1808.

19. Andel M, Polak J, Kraml P, Dlouhy P, Stich V: [Chronic mild inflammation links obesity, metabolic syndrome, atherosclerosis and diabetes]. Vnitr Lek 2009, 55(7-8):659-665.

20. Nguyen MT, Favelyukis S, Nguyen AK, Reichart D, Scott PA, Jenn A, LiuBryan R, Glass CK, Neels JG, Olefsky JM: A subpopulation of macrophages infiltrates hypertrophic adipose tissue and is activated by free fatty acids via Toll-like receptors 2 and 4 and JNK-dependent pathways. J Biol Chem 2007, 282(48):35279-35292.

21. Senn JJ: Toll-like Receptor-2 Is Essential for the Development of Palmitate-induced Insulin Resistance in Myotubes. Journal of Biological Chemistry 2006, 281(37):26865-26875.

22. Shi H, Kokoeva MV, Inouye K, Tzameli I, Yin H, Flier JS: TLR4 links innate immunity and fatty acid induced insulin resistance. The Journal of Clinical Investigation 2006, 116(11):3015-3025.

23. Takeda K, Kaisho T, Akira S: Toll-like receptors. Annual Review of Immunology 2003, 21(1):335-376.

24. Tamrakar AK, Schertzer JD, Chiu TT, Foley KP, Bilan PJ, Philpott DJ, Klip A: NOD2 activation induces muscle cell-autonomous innate immune responses and insulin resistance. Endocrinology 2010, 151(12):5624-5637.

25. Catalan V, Gomez-Ambrosi J, Ramirez B, Rotellar F, Pastor C, Silva C, Rodriguez A, Gil MJ, Cienfuegos JA, Fruhbeck G: Proinflammatory cytokines in obesity: impact of type 2 diabetes mellitus and gastric bypass. Obes Surg 2007, 17(11):1464-1474.

26. Dinarello CA: Role of pro- and anti-inflammatory cytokines during inflammation: experimental and clinical findings. J Biol Regul Homeost Agents 1997, 11(3):91-103.

27. Kabelitz D, Medzhitov R: Innate immunity-cross-talk with adaptive immunity through pattern recognition receptors and cytokines. Curr Opin Immunol 2007, 19(1):1-3.

28. Matsuzawa Y, Shimomura I, Kihara S, Funahashi T: Importance of adipocytokines in obesity-related diseases. Horm Res 2003, 60(Suppl 3):56-59.

29. Nishimura S, Manabe I, Nagai R: Adipose tissue inflammation in obesity and metabolic syndrome. Discov Med 2009, 8(41):55-60.

30. Sell H, Dietze-Schroeder D, Kaiser U, Eckel J: Monocyte chemotactic protein-1 is a potential player in the negative cross-talk between adipose tissue and skeletal muscle. Endocrinology 2006, 147(5):2458-2467.

31. Bergman RN, Ader M: Free Fatty Acids and Pathogenesis of Type 2 Diabetes Mellitus. Trends in Endocrinology and Metabolism 2000, 11(9):351-356.

32. van Herpen NA, Schrauwen-Hinderling VB: Lipid accumulation in nonadipose tissue and lipotoxicity. Physiol Behav 2008, 94(2):231-241.

33. Turpin SM, Ryall JG, Southgate R, Darby I, Hevener AL, Febbraio MA, Kemp BE, Lynch GS, Watt MJ: Examination of 'lipotoxicity' in skeletal muscle of high-fat fed and ob/ob mice. J Physiol 2009, 587(Pt 7):1593-1605.

34. Sell H, Eckel J: Chemotactic cytokines, obesity and type 2 diabetes: in vivo and in vitro evidence for a possible causal correlation? Proc Nutr Soc 2009, 68(4):378-384.

35. Kleinridders A, Schenten D, Konner AC, Belgardt BF, Mauer J, Okamura T, Wunderlich FT, Medzhitov R, Bruning JC: MyD88 signaling in the CNS is required for development of fatty acid-induced leptin resistance and diet-induced obesity. Cell Metab 2009, 10(4):249-259.

36. Velloso LA, Araujo EP, de Souza CT: Diet-induced inflammation of the hypothalamus in obesity. Neuroimmunomodulation 2008, 15(3):189-193.

37. Wisse BE, Schwartz MW: Does hypothalamic inflammation cause obesity? Cell Metab 2009, 10(4):241-242.

38. Yu J, Shi L, Wang H, Bilan PJ, Yao Z, Samaan MC, He Q, Klip A, Niu W: Conditioned medium from hypoxia-treated adipocytes renders muscle cells insulin resistant. Eur J Cell Biol 2011, 90(12):1000-1015.

39. Trayhurn $P$, Wang $B$, Wood IS: HIF-1alpha protein rather than mRNA as a marker of hypoxia in adipose tissue in obesity: focus on "inflammation is associated with a decrease of lipogenic factors in omental fat in women," by Poulain-Godefroy et al. Am J Physiol Regul Integr Comp Physiol 2008, 295(4):R1097, author reply R1098.

40. Ye J: Emerging Role of Adipose Tissue Hypoxia in Obesity and Insulin Resistance. Int J Obes (Lond) 2009, 33(1):54-66.

41. Calabro P, Yeh ET: Obesity, inflammation, and vascular disease: the role of the adipose tissue as an endocrine organ. Subcell Biochem 2007, 42:63-91.

42. Clement K, Vega N, Laville M, Pelloux V, Guy-Grand B, Basdevant A, Vidal H: Adipose tissue gene expression in patients with a loss of function mutation in the leptin receptor. Int J Obes Relat Metab Disord 2002, 26(12):1533-1538.

43. Farooqi IS, Jebb SA, Langmack G, Lawrence $E$, Cheetham CH, Prentice AM, Hughes IA, McCamish MA, O'Rahilly S: Effects of recombinant leptin therapy in a child with congenital leptin deficiency. N Engl J Med 1999, 341(12):879-884

44. Faroogi IS, O'Rahilly S: Leptin: a pivotal regulator of human energy homeostasis. Am J Clin Nutr 2009, 89(3):980S-984S.

45. Harsch IA, Bergmann T, Koebnick C, Wiedmann R, Ruderich F, Hahn EG, Konturek PC: Adiponectin, resistin and subclinical inflammation-the metabolic burden in Launois Bensaude Syndrome, a rare form of obesity. J Physiol Pharmacol 2007, , 58 Suppl 1: 65-76.

46. La Cava A, Alviggi C, Matarese G: Unraveling the multiple roles of leptin in inflammation and autoimmunity. J Mol Med 2004, 82(1):4-11.

47. Martin SS, Qasim A, Reilly MP: Leptin resistance: a possible interface of inflammation and metabolism in obesity-related cardiovascular disease. J Am Coll Cardiol 2008, 52(15):1201-1210.

48. McTernan PG, Fisher FM, Valsamakis G, Chetty R, Harte A, McTernan CL, Clark PM, Smith SA, Barnett AH, Kumar S: Resistin and type 2 diabetes: regulation of resistin expression by insulin and rosiglitazone and the effects of recombinant resistin on lipid and glucose metabolism in human differentiated adipocytes. J Clin Endocrinol Metab 2003, 88(12):6098-6106.

49. Trayhurn P, Wood IS: Adipokines: inflammation and the pleiotropic role of white adipose tissue. Br J Nutr 2004, 92(3):347-355.

50. Trayhurn P, Wood IS: Signalling role of adipose tissue: adipokines and inflammation in obesity. Biochem Soc Trans 2005, 33(Pt 5):1078-1081.

51. Elgazar-Carmon V, Rudich A, Hadad N, Levy R: Neutrophils transiently infiltrate intra-abdominal fat early in the course of high-fat feeding. $J$ Lipid Res 2008, 49(9):1894-1903.

52. Takeya M: [Monocytes and macrophages-multifaced cell population involved in inflammation, atherosclerosis, and obesity]. Nippon Rinsho 2005, 63(Suppl 4):117-122.

53. Goodpaster BH, Wolf D: Skeletal muscle lipid accumulation in obesity, insulin resistance, and type 2 diabetes. Pediatr Diabetes 2004, 5(4):219-226.

54. Shoelson SE, Lee J, Yuan M: Inflammation and the IKK beta/I kappa B/NFkappa B axis in obesity- and diet-induced insulin resistance. Int J Obes Relat Metab Disord 2003, 27(Suppl 3):S49-52.

55. Sartipy P, Loskutoff DJ: Monocyte chemoattractant protein 1 in obesity and insulin resistance. Proc Natl Acad Sci USA 2003, 100(12):7265-7270.

56. Marette A: Molecular mechanisms of inflammation in obesity-linked insulin resistance. Int J Obes Relat Metab Disord 2003, 27(Suppl 3):S46-48.

57. Hotamisligil GS: Inflammatory pathways and insulin action. Int J Obes Relat Metab Disord 2003, 27(Suppl 3):S53-55.

58. Ilan Y, Maron R, Tukpah AM, Maioli TU, Murugaiyan G, Yang K, Wu HY, Weiner $\mathrm{HL}$ : Induction of regulatory $\mathrm{T}$ cells decreases adipose inflammation and alleviates insulin resistance in ob/ob mice. Proc Natl Acad Sci USA 107(21):9765-9770.

59. Lumeng CN, Maillard I, Saltiel AR: T-ing up inflammation in fat. Nat Med 2009, 15(8):846-847.

60. Kintscher U, Hartge M, Hess K, Foryst-Ludwig A, Clemenz M, Wabitsch M, Fischer-Posovszky P, Barth TF, Dragun D, Skurk T, et al: T-lymphocyte infiltration in visceral adipose tissue: a primary event in adipose tissue inflammation and the development of obesity-mediated insulin resistance. Arterioscler Thromb Vasc Biol 2008, 28(7):1304-1310.

61. Plomgaard P, Bouzakri K, Krogh-Madsen R, Mittendorfer B, Zierath JR, Pedersen BK: Tumor Necrosis Factor-Î士 Induces Skeletal Muscle Insulin Resistance in Healthy Human Subjects via Inhibition of Akt Substrate 160 Phosphorylation. Diabetes 2005, 54(10):2939-2945.

62. Mercurio F, Zhu H, Murray BW, Shevchenko A, Bennett BL, Li JW, Young DB, Barbosa M, Mann M, Manning A, et al: IKK-1 and IKK-2: Cytokine-Activated 
IkB Kinases Essential for NF-kB Activation. Science 1997, 278(5339):860-866

63. Yin MJ, Yamamoto Y, Gaynor RB: The anti-inflammatory agents aspirin and salicylate inhibit the activity of I(kappa)B kinase-beta. Nature 1998, 396(6706):77-80

64. Arkan MC, Hevener AL, Greten FR, Maeda S, Li ZW, Long JM, WynshawBoris A, Poli G, Olefsky J, Karin M: IKK-beta links inflammation to obesityinduced insulin resistance. Nat Med 2005, 11(2):191-198.

65. Vallerie SN, Furuhashi M, Fucho R, Hotamisligil GS: A predominant role for parenchymal c-Jun amino terminal kinase (JNK) in the regulation of systemic insulin sensitivity. PLOS One 2008, 3(9):e3151.

66. Hirosumi J, Tuncman G, Chang L, Gorgun CZ, Uysal KT, Maeda K, Karin M, Hotamisligil GS: A central role for JNK in obesity and insulin resistance. Nature 2002, 420(6913):333-336.

67. Aguirre V, Uchida T, Yenush L, Davis R, White MF: The c-Jun NH(2)-terminal kinase promotes insulin resistance during association with insulin receptor substrate-1 and phosphorylation of Ser(307). J Biol Chem 2000, 275(12):9047-9054

68. Solinas G, Karin M: JNK1 and IKKß: molecular links between obesity and metabolic dysfunction. The FASEB Journal 24(8):2596-2611.

69. Hotamisligil GS: Role of endoplasmic reticulum stress and c-Jun NH2terminal kinase pathways in inflammation and origin of obesity and diabetes. Diabetes 2005, 54(Suppl 2):S73-78.

70. Kim JK, Fillmore JJ, Sunshine MJ, Albrecht B, Higashimori T, Kim DW, Liu ZX, Soos TJ, Cline GW, O'Brien WR, et al: PKC-theta knockout mice are protected from fat-induced insulin resistance. J Clin Invest 2004, 114(6):823-827.

71. Liu YF, Paz K, Herschkovitz A, Alt A, Tennenbaum T, Sampson SR, Ohba M, Kuroki T, LeRoith D, Zick Y: Insulin stimulates PKCzeta -mediated phosphorylation of insulin receptor substrate-1 (IRS-1). A self-attenuated mechanism to negatively regulate the function of IRS proteins. J Biol Chem 2001, 276(17):14459-14465.

72. Haasch D, Berg C, Clampit JE, Pederson T, Frost L, Kroeger P, Rondinone CM: PKCtheta is a key player in the development of insulin resistance. Biochem Biophys Res Commun 2006, 343(2):361-368.

73. Samuel VT, Liu ZX, Wang A, Beddow SA, Geisler JG, Kahn M, Zhang XM, Monia BP, Bhanot S, Shulman GI: Inhibition of protein kinase Cepsilon prevents hepatic insulin resistance in nonalcoholic fatty liver disease. J Clin Invest 2007, 117(3):739-745.

74. Kosteli A, Sugaru E, Haemmerle G, Martin JF, Lei J, Zechner R, Ferrante AW $\mathrm{Jr}$ : Weight loss and lipolysis promote a dynamic immune response in murine adipose tissue. J Clin Invest 2010, 120(10):3466-3479.

75. Guilherme A, Virbasius JV, Puri V, Czech MP: Adipocyte dysfunctions linking obesity to insulin resistance and type 2 diabetes. Nat Rev Mol Cell Biol 2008, 9(5):367-377.

76. Patsouris D, Neels JG, Fan W, Li PP, Nguyen MT, Olefsky JM: Glucocorticoids and thiazolidinediones interfere with adipocytemediated macrophage chemotaxis and recruitment. J Biol Chem 2009, 284(45):31223-31235.

77. Goodpaster BH, He J, Watkins S, Kelley DE: Skeletal Muscle Lipid Content and Insulin Resistance: Evidence for a Paradox in Endurance-Trained Athletes. Journal of Clinical Endocrinology \& Metabolism 2001, 86(12):5755-5761.

78. van Loon LJC, Koopman R, Manders R, van der Weegen W, van Kranenburg GP, Keizer HA: Intramyocellular lipid content in type 2 diabetes patients compared with overweight sedentary men and highly trained endurance athletes. American Journal of Physiology - Endocrinology And Metabolism 2004, 287(3):E558-E565.

79. Yu C, Chen Y, Cline GW, Zhang D, Zong H, Wang Y, Bergeron R, Kim JK, Cushman SW, Cooney GJ, et al: Mechanism by Which Fatty Acids Inhibit Insulin Activation of Insulin Receptor Substrate-1 (IRS-1)-associated Phosphatidylinositol 3-Kinase Activity in Muscle. Journal of Biological Chemistry 2002, 277(52):50230-50236.

80. Shulman Gl: Cellular mechanisms of insulin resistance. J Clin Invest 2000, 106(2):171-176.

81. Hotamisligil GS, Shargill NS, Spiegelman BM: Adipose expression of tumor necrosis factor-alpha: direct role in obesity-linked insulin resistance. Science 1993, 259:87-91.

82. Bourlier $\mathrm{V}$, Bouloumie $\mathrm{A}$ : Role of macrophage tissue infiltration in obesity and insulin resistance. Diabetes Metab 2009, 35(4):251-260.
83. Bruun JM, Lihn AS, Pedersen SB, Richelsen B: Monocyte Chemoattractant Protein-1 Release Is Higher in Visceral than Subcutaneous Human Adipose Tissue (AT): Implication of Macrophages Resident in the AT. J Clin Endocrinol Metab 2005, 90(4):2282-2289.

84. Chavey C, Lazennec G, Lagarrigue S, Clape C, lankova I, Teyssier J, Annicotte JS, Schmidt J, Mataki C, Yamamoto H, et al: CXC ligand 5 is an adipose-tissue derived factor that links obesity to insulin resistance. Cell Metab 2009, 9(4):339-349.

85. Lacasa D, Taleb S, Keophiphath M, Miranville A, Clement K: Macrophagesecreted factors impair human adipogenesis: involvement of proinflammatory state in preadipocytes. Endocrinology 2007 148(2):868-877.

86. Janeway CA, Medzhitov R: Innate Immune Recognition. Annual Review of Immunology 2002, 20(1):197-216.

87. Karagiannides I, Pothoulakis C: Obesity, innate immunity and gut inflammation. Curr Opin Gastroenterol 2007, 23(6):661-666.

88. Medzhitov R: Recognition of microorganisms and activation of the immune response. Nature 2007, 449(7164):819-826.

89. Lumeng CN, DelProposto JB, Westcott DJ, Saltiel AR: Phenotypic switching of adipose tissue macrophages with obesity is generated by spatiotemporal differences in macrophage subtypes. Diabetes 2008, 57(12):3239-3246.

90. Lumeng CN, Deyoung SM, Bodzin JL, Saltiel AR: Increased inflammatory properties of adipose tissue macrophages recruited during diet-induced obesity. Diabetes 2007, 56(1):16-23.

91. Lumeng CN, Bodzin JL, Saltiel AR: Obesity induces a phenotypic switch in adipose tissue macrophage polarization. J Clin Invest 2007, 117(1):175-184.

92. Gordon S, Martinez FO: Alternative activation of macrophages: mechanism and functions. Immunity 32(5):593-604.

93. Martinez FO, Helming L, Gordon S: Alternative activation of macrophages: an immunologic functional perspective. Annu Rev Immunol 2009, 27:451-483.

94. Zeyda M, Farmer D, Todoric J, Aszmann O, Speiser M, Gyori G, Zlabinger GJ, Stulnig TM: Human adipose tissue macrophages are of an antiinflammatory phenotype but capable of excessive pro-inflammatory mediator production. Int J Obes 2007, 31(9):1420-1428.

95. Zeyda M, Stulnig TM: Adipose tissue macrophages. Immunology Letters 2007, 112(2):61-67.

96. Hume DA: The mononuclear phagocyte system. Curr Opin Immunol 2006, 18(1):49-53

97. Hume DA: Differentiation and heterogeneity in the mononuclear phagocyte system. Mucosal Immunol 2008, 1(6):432-441.

98. Gordon S: The macrophage: past, present and future. Eur J Immunol 2007, 37(Suppl 1):S9-17.

99. Gordon S: Macrophage heterogeneity and tissue lipids. J Clin Invest 2007, 117(1):89-93.

100. Varin A, Gordon S: Alternative activation of macrophages: immune function and cellular biology. Immunobiology 2009, 214(7):630-641.

101. Ricardo-Gonzalez RR, Red Eagle A, Odegaard Jl, Jouihan H, Morel CR, Heredia JE, Mukundan L, Wu D, Locksley RM, Chawla A: IL-4/STAT6 immune axis regulates peripheral nutrient metabolism and insulin sensitivity. Proc Natl Acad Sci USA 2010, 107(52):22617-22622.

102. Odegaard Jl, Ricardo-Gonzalez RR, Goforth MH, Morel CR, Subramanian V, Mukundan L, Red Eagle A, Vats D, Brombacher F, Ferrante AW, et al: Macrophage-specific PPARgamma controls alternative activation and improves insulin resistance. Nature 2007, 447(7148):1116-1120.

103. Odegaard JI, Chawla A: Alternative macrophage activation and metabolism. Annu Rev Pathol 2011, 6:275-297.

104. Cybulsky MI, Lichtman AH, Hajra L, liyama K: Leukocyte adhesion molecules in atherogenesis. Clin Chim Acta 1999, 286(1-2):207-218.

105. Ley K, Laudanna C, Cybulsky MI, Nourshargh S: Getting to the site of inflammation: the leukocyte adhesion cascade updated. Nat Rev Immunol 2007, 7(9):678-689

106. Aron-Wisnewsky J, Tordjman J, Poitou C, Darakhshan F, Hugol D, Basdevant A, Aissat A, Guerre-Millo M, Clement K: Human adipose tissue macrophages: $\mathrm{m} 1$ and $\mathrm{m} 2$ cell surface markers in subcutaneous and omental depots and after weight loss. J Clin Endocrinol Metab 2009, 94(11):4619-4623.

107. Geissmann Fdr, Gordon S, Hume DA, Mowat AM, Randolph GJ: Unravelling mononuclear phagocyte heterogeneity. Nat Rev Immunol 10(6):453-460. 
108. Charriére G, Cousin B, Arnaud E, André M, Bacou F, Pénicaud L, Casteilla L: Preadipocyte Conversion to Macrophage. Journal of Biological Chemistry 2003, 278(11):9850-9855.

109. Cousin B, Andre M, Casteilla L, Penicaud L: Altered macrophage-like functions of preadipocytes in inflammation and genetic obesity. J Cell Physiol 2001, 186(3):380-386.

110. Cousin B, Munoz O, Andre M, Fontanilles AM, Dani C, Cousin JL, Laharrague $P$, Casteilla $L$, Penicaud $L$ : A role for preadipocytes as macrophage-like cells. FASEB J 1999, 13(2):305-312.

111. Aqel NM, Ball RY, Waldmann H, Mitchinson MJ: Monocytic origin of foam cells in human atherosclerotic plaques. Atherosclerosis 1984, 53(3):265-271.

112. Palmer AM, Murphy N, Graham A: Triglyceride-rich lipoproteins inhibit cholesterol efflux to apolipoprotein (apo) A1 from human macrophage foam cells. Atherosclerosis 2004, 173(1):27-38.

113. Tian L, Luo N, Klein RL, Chung BH, Garvey WT, Fu Y: Adiponectin reduces lipid accumulation in macrophage foam cells. Atherosclerosis 2009, 202(1):152-161.

114. Wellen KE, Hotamisligil GS: Obesity-induced inflammatory changes in adipose tissue. J Clin Invest 2003, 112(12):1785-1788.

115. Wellen KE, Hotamisligil GS: Inflammation, stress, and diabetes. J Clin Invest 2005, 115(5):1111-1119.

116. de Souza CJ, Eckhardt M, Gagen K, Dong M, Chen W, Laurent D, Burkey BF: Effects of Pioglitazone on Adipose Tissue Remodeling Within the Setting of Obesity and Insulin Resistance. Diabetes 2001, 50(8):1863-1871.

117. Suganami T, Ogawa Y: Adipose tissue macrophages: their role in adipose tissue remodeling. Journal of Leukocyte Biology 2010, 88(1):33-39.

118. Hotamisligil GS: Mechanisms of TNF-alpha-induced insulin resistance. Exp Clin Endocrinol Diabetes 1999, 107(2):119-125.

119. Hotamisligil GS: Molecular mechanisms of insulin resistance and the role of the adipocyte. Int J Obes Relat Metab Disord 2000, 24(Suppl 4):S23-27.

120. Saltiel $A R$, Kahn CR: Insulin signalling and the regulation of glucose and lipid metabolism. Nature 2001, 414(6865):799-806.

121. Dietze D, Koenen M, Röhrig K, Horikoshi H, Hauner H, Eckel J: Impairment of Insulin Signaling in Human Skeletal Muscle Cells by Co-Culture With Human Adipocytes. Diabetes 2002, 51(8):2369-2376.

122. Holloway GP, Bonen A, Spriet LL: Regulation of skeletal muscle mitochondrial fatty acid metabolism in lean and obese individuals. Am J Clin Nutr 2009, 89(1):455S-462.

123. Samokhvalov V, Bilan PJ, Schertzer JD, Antonescu CN, Klip A: Palmitateand lipopolysaccharide-activated macrophages evoke contrasting insulin responses in muscle cells. Am J Physiol Endocrinol Metab 2009, 296(1): E37-46.

124. Hong E-G, Ko HJ, Cho Y-R, Kim H-J, Ma Z, Yu TY, Friedline RH, Kurt-Jones $E_{\text {, }}$ Finberg R, Fischer MA, et al: Interleukin-10 Prevents Diet-Induced Insulin Resistance by Attenuating Macrophage and Cytokine Response in Skeletal Muscle. Diabetes 2009, 58(11):2525-2535.

125. Hevener AL, Olefsky JM, Reichart D, Nguyen MT, Bandyopadyhay G, Leung HY, Watt MJ, Benner C, Febbraio MA, Nguyen AK, et al: Macrophage PPAR gamma is required for normal skeletal muscle and hepatic insulin sensitivity and full antidiabetic effects of thiazolidinediones. J Clin Invest 2007, 117(6):1658-1669.

126. Patsouris D, Li PP, Thapar D, Chapman J, Olefsky JM, Neels JG: Ablation of CD11c-positive cells normalizes insulin sensitivity in obese insulin resistant animals. Cell Metab 2008, 8(4):301-309.

127. Varma V, Yao-Borengasser A, Rasouli N, Nolen GT, Phanavanh B, Starks T, Gurley C, Simpson P, McGehee RE Jr, Kern PA, et al: Muscle inflammatory response and insulin resistance: synergistic interaction between macrophages and fatty acids leads to impaired insulin action. Am J Physiol Endocrinol Metab 2009, 296(6):E1300-1310.

128. Di Gregorio GB, Yao-Borengasser A, Rasouli N, Varma V, Lu T, Miles LM, Ranganathan G, Peterson CA, McGehee RE, Kern PA: Expression of CD68 and macrophage chemoattractant protein-1 genes in human adipose and muscle tissues: association with cytokine expression, insulin resistance, and reduction by pioglitazone. Diabetes 2005, 54(8):2305-2313.

129. Bruun JM, Helge JW, Richelsen B, Stallknecht B: Diet and exercise reduce low-grade inflammation and macrophage infiltration in adipose tissue but not in skeletal muscle in severely obese subjects. Am J Physiol Endocrinol Metab 2006, 290(5):E961-967.

130. Tordjman J, Guerre-Millo M, Clement K: Adipose tissue inflammation and liver pathology in human obesity. Diabetes Metab 2008, 34(6 Pt 2):658-663.
131. Clementi AH, Gaudy AM, van Rooijen N, Pierce RH, Mooney RA: Loss of Kupffer cells in diet-induced obesity is associated with increased hepatic steatosis, STAT3 signaling, and further decreases in insulin signaling. Biochimica et Biophysica Acta (BBA) - Molecular Basis of Disease 2009, 1792(11):1062-1072.

132. Obstfeld AE, Sugaru E, Thearle M, Francisco AM, Gayet C, Ginsberg HN, Ables EV, Ferrante AW Jr: C-C chemokine receptor 2 (CCR2) regulates the hepatic recruitment of myeloid cells that promote obesity-induced hepatic steatosis. Diabetes 2010, 59(4):916-925.

133. Yang $\mathrm{S}$, IglayReger $\mathrm{H}$, Kadouh $\mathrm{H}$, Bodary P: Inhibition of the chemokine (C$\mathrm{C}$ motif) ligand $2 /$ chemokine ( $\mathrm{C}-\mathrm{C}$ motif) receptor 2 pathway attenuates hyperglycaemia and inflammation in a mouse model of hepatic steatosis and lipoatrophy. Diabetologia 2009, 52(5):972-981.

134. Park EJ, Lee JH, Yu G-Y, He G, Ali SR, Holzer RG, $\div$ sterreicher $\mathrm{CH}_{\text {, }}$ Takahashi H, Karin M: Dietary and Genetic Obesity Promote Liver Inflammation and Tumorigenesis by Enhancing IL-6 and TNF Expression. Cell 2010, 140(2):197-208.

doi:10.1186/1758-5996-3-29

Cite this article as: Samaan: The macrophage at the intersection of immunity and metabolism in obesity. Diabetology \& Metabolic Syndrome 2011 3:29.

\section{Submit your next manuscript to BioMed Central and take full advantage of:}

- Convenient online submission

- Thorough peer review

- No space constraints or color figure charges

- Immediate publication on acceptance

- Inclusion in PubMed, CAS, Scopus and Google Scholar

- Research which is freely available for redistribution

Submit your manuscript at www.biomedcentral.com/submit
Ciomed Central 